\title{
KEKERASAN DALAM RUMAH TANGGA (Analisis Dalam Perspektif Hukum Dan Kebiasaan Masyarakat Desa)
}

\author{
Idham*1 $^{* 1}$ Novi Puspita Sari, ${ }^{2}$ Siti Ayunah. ${ }^{3}$ \\ Fakultas Hukum Universitas Sang Bumi Ruwa Jurai \\ Program Studi Ilmu Hukum \\ idhammanaf07@gmail.com,Novipuspitasari505@gmail.com,sitiayunahh@gmail.com.
}

\begin{abstract}
Abstrak
Kekerasan dalam rumah tangga merupakan perkara dengan multi dimensi baik penyebabnya maupun penyelesaiayan karena terdapat ruang lingkup pidana dan perdata bahkan kekarasan di dalam rumah tangga seringkali dianggap hal biasa bagi masyarakat pedesaan. Maka sebab itu dibutuhkan suatu media di dalam sistem yang dapat mengakomodasi penyelesaian. Permalasahan dalam penelitian ini adalah kekerasan dalam rumah tangga menurut hukum positif dan korelasi kekerasan dalam rumah tangga ditinjau dari kebiasaan pada masyarakat desa.Jenis dan sumber data yang digunakan adalah jenis data sekunder dan sumber data sekunder. Teknik pengumpulan data yang digunakan yaitu studi lapangan di Pekon Panutan Kec. Pegelaran Kab. Pringsewu dan studi dokumen, berupa peraturan perundang-undangan, buku-buku, jurnal, makalah, artikel, dan lain lain analisis yang digunakan dalam penelitian ini mengunakan analisis deskriptif analitis dengan menggunakan pola pikir deduktif. Kesimpulan bahwa pelanggaran terhadap Undang-undang No. 23 Tahun 2004 tentang kekerasan dalam rumah tangga dikategorikan sebagai tindakan yang dilarang dan dikategorikan sebagai tindak pidana yang pelakunya patut dihukum. Kriteria tindak kekerasan terhadap istri yang dianggap sebagai tindak pidana yaitu kekerasan fisik, psikis, seksual dan penelantaran. Rendahnya pengetahuan pada masyarakat desa dan faktor budaya atau adat, kekerasan dalam rumah tangga sebagai dianggap hal yang biasa.
\end{abstract}

Kata Kunci: Kekerasan, Rumah, Tangga.

\begin{abstract}
Violence "in household is a multi-dimensional case both in its cause and in its resolution because there is a scope for criminal and civil and even violence within the household which is common for rural communities. So because of that we need a media in the system that can accommodate the settlement. The problem in this research is domestic violence according to positive law and domestic violence in terms of habits in the village community. The types and sources of data used are secondary data and secondary data sources. The data technique used was a field study at Pekon Panutan Kec. Pegelaran Kab. Pringsewu and document studies, in the form of regulations, books, journals, papers, articles, and other analyzes used in this study used descriptive analytical analysis using a deductive mindset. "The conclusion is that violations of Law no. 23 of 2004 concerning domestic violence is categorized as a prohibited act and is categorized as a prohibited crime. Violence against a wife who is a criminal act of physical, psychological, sexual violence and neglect. Low knowledge of village communities and cultural or customary factors, violence in household as commonplace.
\end{abstract}

Keywords: Violence, Home, Household.

\section{PENDAHULUAN}

Perkembangan hukum pidana dalam Tindak Pidana Kekerasan Dalam Rumah Tangga (KDRT) merupakan perkembangan dari Kitab Undang-Undang Hukum Pidana (KUHP). Tindak Pidana Kekerasan Dalam Rumah Tangga merupakan pidana tertentu yang diatur di luar KUHP, sebagaimana Pasal 28 G ayat (1) UUD 1945 amandemen ke dua menyebutkan bahwa: "Setiap orang berhak atas perlindungan diri pribadi, keluarga, kehormatan, martabat dan harta benda yang dibawah kekuasaannya, serta berhak atas rasa aman dan perlindungan dari ancaman ketakutan untuk berbuat atau tidak berbuat sesuatu yang merupakan hak asasi”. Hermien Hadiati Koeswadji, mengatakan perbuatan pidana tertentu yang diatur dalam peraturan khusus di luar KUHP diartikan dengan hukum pidana yang khusus. Tindak pidana tersebut memiliki 
karakteristik tersendiri, terletak pada subjeknya yang spesifik yaitu pelaku sekaligus korbannya berada dalam lingkup rumah tangga.

Ketentuan dasar tersebut pada hakikatnya negara memberikan jaminan bagi perlindungan pribadi, keluarga dan masyarakat yang diwujudkan dengan pembangunan serta pembaharuan hukum yang sesuai, dengan demikian dalam pembaharuan hukum termasuk hukum pidana harus mempertimbangkan nilai-nilai yang hidup dalam masyarakat (Putra Jaya, 2005).

Subjek hukum KDRT pada ketentuan tersebut merupakan person dan sub ordinat yang berada dalam ruang dan waktu tertentu. Sejatinya pemernintah bertanggung jawab dalam upaya pencegahan KDRT. Hak mendapat perlindungan individu dan keluarga dijamin oleh negara sebagaimana isi penjelasan Ketentuan Umum Undang-Undang Nomor 23 Tahun 2004 tentang Penghapusan Kekerasan Dalam Rumah Tangga. Makna sesungguhnya Penghapusan kekerasan dalam rumah tangga dalam undang-undang ini adalah mencegah segala bentuk kekerasan dalam rumah tangga (tujuan preventif), melindungi korban kekerasan dalam rumah tangga (tujuan protektif), menindak pelaku kekerasan dalam rumah tangga (tujuan represif), dan memelihara keutuhan rumah tangga yang harmonis dan sejahtera (tujuan konsolidatif) yang merupakan perwujudan prinsip persamaan hak dan penghargaan terhadap martabat manusia.

Sehubungan dengan karakteristik perkara KDRT, menurut (Harkrisnowo, 2004), Domestic violence atau di Indonesia dikenal dengan Kejahatan "Kekerasan Dalam Rumah Tangga (KDRT)", mempunyai kekhususan dibandingkan dengan bentuk-bentuk lain dari kekerasan terhadap perempuan oleh karena adanya hubungan yang berkenaan dengan kekuasaan (power relationship) antara korban dan pelaku. Beban psikologis yang dialami perempuan korban KDRT sangat tinggi karena hubungan kekuasaan selalu mengandung unsur kepercayaan dan juga unsur dependensi sampai pada tingkat tertentu. Selain merasa adanya abuse of power oleh pemilik kekuasaan tersebut, korban juga pada umumnya mengalami ketakutan, keengganan, dan juga malu untuk melaporkan kepada yang berwajib.

Kekerasan dalam rumah tangga merupakan pelanggaran atau suatu kejahatan yang dialami manusia serta merupakan bentuk diskriminasi. Kekerasan dalam rumah tangga (KDRT) adalah setiap perbuatan kejahatan yang sering dimenimpah perempuan, yang akan berakibat timbul penderitaan baik secara fisik, psikis, seksual maupun psikologi, dan pelantaran juga termasuk ancaman untuk melakukan perbuatan, pemaksaan dan perampasan secara melawan hukum dalam lingkup rumah tangga. Negara berpandangan bahwa segala bentuk kekerasan terutama kekerasan dalam rumah tangga adalah pelanggaran hak asasi manusia dan kejahatan terhadap martabat kemanusiaan serta bentuk diskriminasi. Pandangan negara tersebut didasarkan pada Pasal 28 Undang-undang Dasar Negara Republik Indonesia tahun 1945, beserta perubahannya. Pasal. 28 g ayat (1) Undang-Undang Dasar tahun 1945 menentukan bahwasetiap, oran berhak atas perlindungan diri pribadi, keluarga, kehormatan, martabat, dan harta benda yang berada di bawah kekuasaannya, serta berhak atas rasa aman dan perlindungan dari ancaman ketakutan untuk berbuat atau tidak berbuat sesuatu yang merupakan hak asasi.

Tindak kekerasan di dalam rumah tangga (domestic violence) merupakan jenis kejahatan yang kurang mendapatkan perhatian dan jangkauan hukum. Tindak kekerasan di dalam rumah tangga pada umumnya melibatkan pelaku dan korban diantara anggota keluarga di dalam rumah tangga, sedangkan bentuk tindak kekerasan bisa berupa kekerasan fisik dan kekerasan verbal (ancaman kekerasan). Pelaku dan korban tindak kekerasan didalam rumah tangga bisa menimpa siapa saja, tidak dibatasi oleh strata, status sosial, tingkat pendidikan, dan suku bangsa. Tindak kekerasan pada istri dalam rumah tangga merupakan masalah sosial yang serius, akan tetapi kurang mendapat tanggapan dari masyarakat dan para penegak hukum karena beberapa alasan, pertama: ketiadaan statistik kriminal yang akurat, kedua: tindak kekerasan pada istri dalam 
rumah tangga memiliki ruang lingkup sangat pribadi dan terjaga privacynya berkaitan dengan kesucian dan keharmonisan rumah tangga (sanctitive of the home), ketiga: tindak kekerasan pada istri dianggap wajar karena hak suami sebagai pemimpin dan kepala keluarga, keempat: tindak kekerasan pada istri dalam rumah tangga terjadi dalam lembaga legal yaitu perkawinan(Hasbianto, 1996).

Kecenderungan tindak kekerasan dalam rumah tangga terjadinya karena faktor dukungan sosial dan kultur (budaya) khususnya pada masyarakar pedesaan, dimana istri menganggap prilaku kekarasan yang dilakukan oleh suami baik secara fisik maupun perbal dan sexual di persepsikan sebagai ujian kesabaran dan ketabahan seorang istri, sehingga semua tindakan kekarasan diterima sebagai cobaan dalam kehidupan rumah tangga. Hal ini muncul karena transformasi pengetahuan yang diperoleh dari masa lalu, istri harus nurut kata suami, bila istri mendebat suami, dipukul. Kultur di masyarakat suami lebih dominan pada istri, ada tindak kekerasan dalam rumah tangga dianggap masalah privasi, masyarakat tidak boleh ikut campur. Sebagaimana yang terjadi pada masyarakat di Pekon Panutan Kecamatan Pagelaran Kabupaten Pringsewu.

Saat ini dengan berlakunya undang-undang anti kekerasan dalam rumah tangga disetujui tahun 2004, maka tindak kekerasan dalam rumah tangga bukan hanya urusan suami istri tetapi sudah menjadi urusan publik. Keluarga dan masyarakat dapat ikut mencegah dan mengawasi bila terjadi kekerasan dalam rumah tangga. Kekerasan dalam rumah tangga menurut Undang-undang RI Nomor. 23 tahun 2004 adalah setiap perbuatan terhadap seseorang terutama perempuan, yang berakibat timbulnya kesengsaraan atau penderitaan secara fisik, seksual, psikologis, dan atau penelantaran rumah tangga termasuk ancaman untuk melakukan perbuatan, pemaksaan, atau perampasan kemerdekaan secara melawan hukum dalam lingkup rumah tangga.

Berdasarkan beberapa uraian di atas, penulis menganggap pentingnya melalukan kajian mengenai aspek hukum kekerasan dalam rumah tangga yang diatur dalam Undang-Undang Nomor 231 tahun 2004 tentang Pengahapusan Kekerasan dalam Rumah Tangga, dengan judu. Kekerasan Rumah Tangga: Analisis Dalam Perspektif Hukum Positif Dan Kebiasaan Masyarakat Desa

\section{METODE PENELITIAN}

Metode penelitian yang digunakan adalah metode penelitian normatif empiris disertai dengan penelitian Studi Pustaka ( Libery reseacrch) dan stuydi lapangan (field research). Selanjutnya, metode penelitian digunakan sesuai dengan rumusan masalah yang menjadi fokus penelitian ini, yaitu masalah Kekerasan dalam rumah tangga dalam persepektif Hukum positif di Indonesia dan korelasi kekerasan dalam rumah tangga ditinjau dari kebiasaan masyarakat desa

Penelitian ini sifatnya yuridis normative dengan jenis penelitian hukum yang mengambil data kepustakaan dan data lapangan dengan menggunakan metode wawancara. Penelitian dan penyuluhan dilakukan di Pekon Panutan Kecamatan Pagelaran Kabupaten Pringsewu.

Penelitian ini bersifat yuridis normative, oleh karenanya menggunakan data sekunder yang terdiri atas :

(a) Bahan hukum primer, yaitu bahan pustaka yang berisikan pengetahuan ilmiah yang baru atau mutakhir ataupun pengertian baru tentang fakta yang diketahui maupun mengenai suatu gagasan atau ide

(b) Bahan hukum sekunder, yaitu bahan pustaka yang berisikan informasi tentang bahan primer, terdiri atas : literatur-literatur. 
Seminar Nasional Penelitian dan Pengabdian kepada Masyarakat Universitas Sang Bumi Ruwa Jurai Tahun 2020

(c) Bahan hukum tersier, yaitu bahan hukum penunjang yang memberikan petunjuk terhadap bahan hukum primer dan sekunder atau dikenal pula dengan nama bahan acuan atau rujukan bidang hukum, antara lain : Kamus Hukum.

Teknik analisis digunakan dengan pendekatan deskriptif normatif serta dikombinasikan dengan fakta-fakta dan kenyataan yang ditemukan di lapangan terutama terkait dengan penerapan aturan-aturan tentang Kekerasan dalam rumah tangga dalam persepektif Hukum positif di Indonesia dan korelasi kekerasan dalam rumah tangga ditinjau dari kebiasaan masyarakat desa.

\section{HASIL DAN PEMBAHASAN}

\section{Defisi Kekerasan Dalam Rumah Tangga.}

Banyak pendapat dan tentang pengertian dan konsep kekerasan dalam rumah tangga, sebagai pembanding terhadap persoalan ini, Gurr mendefinisikan kekerasan politik sebagai berikut: "all collective attacks within a political community against the political regime, its actors - including competing political groups as well as incumbents-or its policies. The concept represents a set of events, a common property of which is the actual or trheatened use of violence .... The concept subsumes revolution, ... guerilla war, coups d'atat, and riots."

Definisi di atas menunjukkan bahwa tindak kekerasan politik amat luas cakupannya, yang meliputi semua kejadian yang unsur utamanya adalah penggunaan atau ancaman penggunaan kekerasan yang dilakukan oleh pelaku/aktor atau kelompok aktor yang menentang penguasa negara. Selain itu, Galtung mendefiniskan kekerasan dalam pengertian yang lebih luas sebagai "any avoidable impediment to self-realization", yang berarti segala sesuatu yang menyebabkan orang terhalang untuk mengaktualisasikan potensi dirinya secara wajar (Mas'oed,2000).

Berdasarkan dua definisi pembanding tersebut, KDRT dapat diartikan sebagai tindakan penggunaan kekuasaan atau wewenang secara sewenang-wenang tanpa batasan (abuse of power) yang dimiliki pelaku, yaitu suami atau istri maupun anggota lain dalam rumah tangga, yang dapat mengancam keselamatan dan hak-hak individual masing-masing. dan atau anggota lain dalam rumah tangga seperti anak-anak, mertua, ipar, dan pembantu.

\section{Cakupan Tindak Kekerasan dalam Rumah Tangga}

Tindak kekerasan dalam rumah tangga sesungguhnya sedikit berbeda dengan tindak kekerasan personal/komunitas yang hanya berdimensi fisik. Tindakan tersebut justru berdimensi luas, yang tidak terbatas hanya pada tindakan secara fisik. Ia termasuk juga tindakan yang menghalang orang untuk berkreasi dan mengaktualisasikan diri sesuai potensi yang dimilikinya, dan tindakan memaksanya untuk bekerja atau memaksimalkan potensi dirinya melebihi batas kemampuannya. Dalam batas-batas tertentu, termasuk juga larangan untuk bekerja dan berpenampilan sesuai keinginan, dan larangan untuk berhubungan dengan orang-orang yang disukai. Karena itu, tindak kekerasan dalam rumah tangga juga memiliki dimensi non-fisik, yang melingkupi seluruh perbuatan yang dapat menyebabkan komitmen untuk saling percaya, berbagi, toleran, dan mencintai antarseluruh angggota dalam rumah tangga sebagaimana dimaksudkan dalam tujuan suci perkawinan dan kehidupan rumah tangga harmoni, tercederai.

Dengan demikian, tindakan suami atau istri melarang pasangannya berpenampilan sesuai keinginannya seperti berbusana muslimah atau berjenggot sekalipun, misalnya, sudah tergolong tindak kekerasan dalam rumah tangga. Terlebih lagi bila cara-cara berpenampilan seperti itu telah disepakati sebelum perkawinan sebagai pilihan bebas masing-masing. Demikian pula 
perilaku selingkuh yang menghadirkan perempuan atau laki-laki idaman lain dalam kehidupan rumah tangga bagaikan istri atau suami sendiri seperti belakangan ini marak di kalangan selebriti dan politisi terhormat kita. Cakupannya masih dapat diluaskan lagi ke bentuk-bentuk pemaksaan lain seperti memaksa anak untuk memilih jenis pendidikan dan bidang studi yang tidak sesuai dengan minat dan potensi dirinya.

Dari penjelasan di atas, KDRT dapat dikelompokkan ke dalam lima bentuk, yaitu:

1. Kekerasan fisik dalam bentuk pemukulan dengan tangan maupun benda, penganiayaan, pengurungan, pemberian beban kerja yang berlebihan, dan pemberian ancaman kekerasan.

2. Kekerasan verbal dalam bentuk caci maki, meludahi, dan bentuk penghinaan lain secara verbal.

3. Kekerasan psikologi atau emosional yang meliputi pembatasan hak-hak individu dan berbagai macam bentuk tindakan teror.

4. Kekerasan ekonomi melalui tindakan pembatasn penggunaan keuangan yang berlebihan dan pemaksaan kehendak untuk untuk kepentingan-kepentingan ekonomi, seperti memaksa untuk bekerja dan sebagainya.

5. Kekerasan seksual dalam bentuk pelecehan seksual yang paling ringan hingga perkosaan (Dermawan, 1999).

\section{Faktor Penyebab Terjadinya Kekerasan Dalam Rumah Tangga}

Kekerasan dalam rumah tangga bukanlah hal yang baru dihadapi oleh para istri atau suami, akan tetapi telah ada semenjak kehiduan manusia membangun rumah tangga. Pemahaman yang jujur dan ikhlas terhadap faktor-faktor yang mendorong terjadinya kekerasan akan menjadi langkah strategis dalam menemukan solusi dari persolan yang dihadapi. Banyak faktor secara empirik telah terbukti memberikan kontribusi terhadap meningkatnya kekerasan dalam rumah tangga. Diantara penyebab itu adalah:

1. Sikap nusyuz istri atau suami yaitu sikap membangkang teradap kewajiban-kewajiban dalam kehidupan perkawinan, seperti istri tidak mau melayani suami pada hal tidak ada uzur seperti haid atau sakit

2. Lemahnya pemahaman atau pengamalan ajaran agama oleh individu umat Islam. Tidak adanya ketaqwaan pada individu, lemahnya pemahaman relasi suami-istri dalam rumah tangga, dan karakteristik yang tempramental juga sebagai pemicu bagi seseorang untuk melanggar hukum syari'at termasuk melakukan tindakan

3. Disisi lain juga disebabkan adanya faktor ekonomi, pendidikan yang rendah, cemburu dan lain sebagainya. Kekerasan dalam rumah tangga yan disebabkan faktor ekonomi, bisa digambarkan karena minimnya penghasilan suami dalam mencukupi kebutuhan rumah tangga. Terkadang adanya istri yang terlalu banyak menuntut untuk memenuhi kebutuhan rumah tangga, baik kebutuhan sandang, pangan maupun kebutuhan pendidikan. Dari situlah berawal pertengkaran antara suami dengan istri yang pada akhirnya menimbulkan kekerasan dalam rumah tangga. Kedua belah pihak tidak lagi saling mengontrol emosinya

\section{Penegakan Hukum Kasus KDRT}

Pada dasarnya istilah kekerasan fisik tidak ditemukan dalam Kitab Undang-Undang Hukum Pidana (KUHP) secara terperinci, yang ada adalah istilah penganiayaan yang secara substansi dapat memberikan pemahaman mengenai kekerasan fisik yang diakibatkan karena 
suatu tindak pidana penganiayaan. Kekerasan fisik dalam tindak penganiayaan seperti diuraikan dalam pasal-pasal KUHP adalah bertujuan merugikan pihak korban secara fisik dan jasmani.Pengertian penganiayaan menurut yurisprudensi adalah adanya tujuan yang patut yang hendak di capai oleh suatu perbuatan yang di sadari (terpaksa) menimbulkan rasa sakit atau luka. Dalam ilmu hukum, penganiayaan diartikan sebagai perbuatan yang dilakukan dengan sengaja untuk menimbulkan rasa sakit (pijn) atau luka (letsel) pada tubuh orang lain.

Berdasarkan pengertian di atas dapat diketahui tentang unsur-unsur penganiayaan, yaitu adanya kesengajaan, adanya perbuatan dan adanya akibat perbuatan yang dituju.

a. Unsur kesengajaan, disebut juga dengan unsur subjektif. Kesengajaan dalam hal ini disamping ditujukan pada perbuatannya itu

b. Adanya perbuatan, disebut dengan unsur objektif. Unsur ini masih bersifat abstrak, karena dengan istilah/kata perbuatan saja, maka dalam bentuknya yang kongkrit tidak terbatas wujudnya. Padahal yang terjadi pada umumnya adalah bahwa perbuatan tersebut mengandung sifat kekerasan fisik dan harus menimbulkan rasa sakit atau luka pada tubuh, dengan kata lain bahwa yang boleh di pidana yaitu mereka yang menciptakan onregt (perbuatan yang melawan hukum).

c. Adanya akibat perbuatan (yang dituju), yaitu rasa sakit dan luka pada tubuh

Berdasarkan pasal 5 Undang-undang Nomor 23 Tahun 2004, dipertegas larangan melakukan kekerasan dalam lingkup rumah tangga, berbunyi : Setiap rang dilarang melakukan kekerasan dalam rumah tangga terhadap orang dalam Iingkup rumah tangganya, dengan cara:

1. Kekerasan fisik

2. Kekerasan psikis

3. Kekerasan seksual

4. Kekerasan ekonomi (penelantaran rumah tangga)

Larangan pada pasal ini mencakup kekerasan fisik, kekerasan psikis atau psikologis, kekerasan seksual dan penelantaran rumah tangga atau kekerasan ekonomi. Pasal 6 menjelaskan perbuatan kekerasan fisik dalam rumah tangga, yakni : "kekerasan fisik sebagaimana dimaksud dalam pasal 5 huruf a adalah perbuatan yang mengakibatkan rasa sakit, jatuh sakit, atau luka berat.

Berdasarkan keterangan Pasal 5 di atas, dapat diambil kesimpulan yakni ada dua unsur kekerasan fisik dalam pengaturan PKDRT yaitu : adanya perbuatan dan adanya akibat perbuatan ditimbulkan.

a. Adanya perbuatan, yaitu adanya perbuatan atau adanya aksi dalam melakukan kekerasan fisik atau penganiayaan berupa memukul, menendang, mencubit, mendorong, baik dengan tangan/kakinya maupun dengan alat atau senjata

b. Adanya akibat perbuatan, yakni adanya akibat dari perbuatan tersebut, yaitu rasa sakit dan luka pada tubuh.

Dalam Kitab Undang-undang Hukum Pidana (KUHP) tidak ditemukan pengaturan khusus mengenai perbuatan pidana yang berkaitan dengan kekerasan dalam rumah tangga. Dalam KUHP hanya mengatur tentang tindak pidana atau delik-delik tentang penganiayaan .Kata aniaya berarti perbuatan bengis seperti perbuatan penyiksaan atau penindasan. Menganiaya artinya memperlakukan sewenang-wenang dengan mempersakiti, atau menyiksa dan sebagainya. Penganiayaan artinya perlakuan yang sewenang-wenang dengan penyiksaan, penindasan dan sebagainya terhadap teraniaya.

Penganiayaan itu sebagai perbuatan yang dilakukan dengan sengaja untuk menimbulkan rasa sakit atau luka kepada orang lain, yang semata-mata merupakan tujuan dari perbuatan 
tersebut. Jika diamati pengaturan pasal-pasal tentang kejahatan terhadap tubuh orang lain dalam KUHP diatur pada pasal 351 sampai 358 KUHP.

Pengaturan tentang delik penganiayaan dalam KUHP dapat dibedakan menjadi 5 macam, sebagai berikut:

1. Penganiayaan ringan (pasal 352 KUHP)

2. Penganiayaan biasa (pasal 351 KUHP)

3. Penganiayaan biasa yang direncanakan terlebih dahulu (pasal 353 KUHP)

4. Penganiayaan berat (pasal $354 \mathrm{KUHP}$ )

5. Penganiayaan berat dengan direncanakan lebih dahulu (pasal 355 KUHP).

Dari uraian di atas pada dasarnya Kitab Undang-Undang Hukum pidana (KUHP) telah mengatur sanksi pidana bagi pelaku kekerasan yang merupakan bagian dari tindak pidana penganiayaan, namun sanksi tersebut belum mengakomodir langsung tindak kekerasan dalam keluarga.

Dengan dikriminalisasikannya perbuatan kekerasan dalam rumah tangga sebagai tindak pidana dalam Undang-undang Nomor 23 Tahun 2004 tentang Penghapusan Kekerasan Dalam Rumah Tangga atau disingkat dengan UU PKDRT, maka UU ini telah menjadi bagian dari sistem hukum pidana positif Indonesia. Karena secara yuridis semua bentuk kekerasan terhadap perempuan, terutama yang terjadi di ranah rumah tangga harus dipandang sebagai kejahatan terhadap kemanusiaan dan merupakan bentuk pelanggaran hak asasi manusia.

PKDRT memperluas defenisi kekerasan tidak hanya sebagai perbuatan yang berakibat timbulnya penderitaan fisik, tetapi juga penderitaan secara psikis. Kekerasan dalam hal ini dirumuskan sebagai delik penganiayaan dan delik kesusilaan psikologis/ psikis, seksual dan penelantaran rumah tangga.

Berkaitan dengan kekerasan fisik terhadap istri atau dalam keluarga telah dijelaskan dalam UU PKDRT, sebagaimana pada pasal 6 dirumuskan sebagai berikut :"Kekerasan fisik sebagaimana dimaksud dalam Pasal 5 huruf a adalah perbuatan yang mengakibatkan rasa sakit, jatuh sakit, atau luka berat.Dalam UU ini suatu perbuatan dapat dikatakan kekerasan fisik jika perbuatan tersebut mengakibatkan rasa sakit, jatuh sakit, atau luka berat bagi korbannya. Ini menandakan bahwa kekerasan fisik tersebut berdampak melukai atau mencederai korban pada anggota tubuhnya, sehingga korban menimbulkan rasa sakit, jatuh sakit atau luka berat.

Jika dipahami, maka pengertian tentang penganiayaan dalam KUHP dan kekerasan maupun kekerasan fisik dalam PKDRT yang telah diuraikan di atas, pada prinsipnya mengandung substansi dan pemahaman yang sama, yaitu perbuatan yang dilakukan sama-sama bentuk penganiayaan yang dapat menimbulkan rasa sakit, menciderai atau dapat merugikan keselamatan nyawa dan tubuh korban.

\section{Kekerasan Rumah Tangga Dalam Kebiasaan Masyarakat Desa.}

Hasil Penelitian menunjukan bahwa berdasarkan hasil wawancara terhadap beberapa ibu rumah tangga di Pekon Panutan Kecamatan Pagelaran Kabupaten Pringsewu diantaranya menyatakan pernah mengalami tindak kekerasan dalam rumah tangga. Berdasarkan data yang dihimpun, terungkap ada 4 (empat) bentuk tindak kekerasan (yaitu : Kekerasan fisik, Kekerasan psykologis, Kekerasan penelantaran keluarga, dan Kekerasan seksual) dalam rumah tangga terhadap perempuan dan anak yang dialami. Keempat bentuk tindakan kekerasan sebagaimana dikemukakan di atas, bentuk kekerasan psykologis yang lebih banyak dialami oleh korban. Jumlah korban yang menyatakan pernah mengalami kekerasan psykologis hampir mendekati 
$100 \%$, sedangkan tindak kekerasan fisik lebih dari sebagian korban yang mengalaminya dan tindakan kekerasan penelantaran keluarga di bawah $50 \%$, serta tindakan kekerasan seksual tidak mencapai $5 \%$.

Menurut Agus Santoso, Kepala Pekon Panutan Kecamatan Pagelaran Kabupaten Pringsewu korban yang mengalami kekerasan fisik pasti mengalami kekerasan psikologis, sebab hampir seluruh korban yang mengalami kekerasan fisik sebelumnya diawali dengan kekerasan psikologis. Demikian juga bagi korban yang mengalami penelantaran keluarga, hampir semua mereka mengalami kekerasan psikologis. Dapat dikatakan bahwa sebelum terjadi peristiwa kekerasan fisik terhadap korban, ada kecenderungan terlebih dahulu dimulai dengan pertengkaran antara korban dengan suami. Ketika telah terjadi percekcokan atau pertengkaran, saat itu juga muncul pernyataan - pernyataan yang menyakiti perasaan hati korban, misalnya, dengan kata sumpah serapah umpatan dan kata-kata kotor seperti anjing, monyet, ancaman cerai dan lain sebagainya. Hal demikian membuat situasi semakin panas dan tidak terkontrol sehingga korban sering mengalami kekerasan fisik, namun demikian perlakukan kekarasan tersebut sedikit sekali yang melapor baik kepada aparat Pekon maupun ke aparat Kepolisian. Temuan penelitian lainnya menunjukkan bahwa akumulasi dari pertengkaran antara korban dengan suami yang pada akhirnya terjadi kekerasan fisik atau kekerasan psikologis, hal ini juga melibatkan anak- anak sebagai bagian yang tidak terpisahkan menjadi korban kekerasan dalam rumah tangga.

Saat wawancara dengan reponden Dewi, umur 48 tahun (tanggal, 19 Oktober 2020), sebagai korban KDRT, mengatakan bahwa ia mengalami kekarasan baik psikis maupun fisik sejak awal menikah sampai dengan terjadinya perceraian kurang lebih 25 tahun berumah tangga, namun demikian tidak pernah melaporkan kasus kekarasan tersebut. Saya tidak pernah melapor dikarenakan apa yang saya alami mungkin sudah suratan hidup saya, sudah takdir saya mendapatkan suami yang bersikap kasar, tidak menafkahi dan tidak perduli terhadap keluarga disamping itu sudah menjadi pesen orang tua ketika akan melangsungkan pernikahan, apapun yang kamu rasakan dari perlakukan suami harus diterima dengan sabar.

Dari sekian banyak responden hampir sama memberikan alasan mengapa tindakan kekerasan dalam rumah tangga yang di alami tidak dilaporkarkan kepada aparat desa mapun aparat kepolisian. Adapun alasan hampir sama, karena akan membuka aip rumah tangga, merasa malu dengan masyarakat, sehingga prilaku kekerasan yang diterima menjadi bagian dari takdir hidup. Disamping itu ketidakpahaman masyarakat terhadap pelindungan pada kekarasan yang dilkukan oleh suami dan dari sekian kasus kekarasan rumah tangga yang terjadi di Pekon Panutan hanya ada 2 orang yang melapor kepada aparat pekon.

\section{Upaya Mencegah Tindak KDRT}

Adanya peristiwa atau kejadian kekarasan dalam Rumah tangga banyak hal positif dapat dipelajari dan diambil manfaatnya dari hubungan-hubungan sosial yang dibangun dalam rumah tangga. KDRT sesungguhnya dapat dihindarkan jika suatu rumah tangga ditegakkan dengan menjalankan berbagai prinsip positif dan etika luhur berdasarkan fungsi anggota menurut hak dan kewajiban masing-masing. Menghapus tindak KDRT dapat dimulai dengan menghilangkan sebab-sebab dan unsur-unsur pemicunya.

Setidaknya terdapat banyak cara dan usaha yang patut dilakukan agar KDRT terelakkan atau setidak-tidaknya dapat dikurangi intensitasnya, antaranya ialah: 


\section{Memperkuat Jaringan Sosial}

Kehidupan rumah tangga merupakan bentuk simpul-simpul, dimana angggota-anggota di dalamnya sesungguhnya merupakan struktur sosial yang mencerminkan jaringan sosial yang diikat dengan tipe relasi spesifik seperti nilai, visi, dan ide bersama serta keturunan. Idealnya, tipe-tipe relasi spesifik itu lah yang berfungsi mengikat aktor-aktor dalam rumah tangga yang terdiri dari anggota-anggotanya seperti suami, istri, anak dan sebagainya dalam suatu hubungan antarsesama yang kuat. Keberhasilan suatu rumah tangga dalam mencapai tujuan-tujuan idealnya, termasuk menghindari terjadinya KDRT, sangat bergantung kepada kekuatan hubungan antar individu bersangkutan

Pada dasarnya semua anggota dalam suatu rumah tangga, terutama suami atau istri yang menjadi antra aktor utama dalam rumah tangga dengan latar belakang sosial yang berbeda seharusnya dapat memperkuat struktur jaringan sosial rumah tangga mereka. Caranya ialah dengan selalu berusaha untuk menyamakan visi, menyeragamkan nilai-nilai dan menyatukan ide dan gagasan masing-masing ke dalam idelaisme dan cita-cita bersama, meskipun untuk itu toleransi yang memadai dari masing-masing pihak amat diperlukan.

\section{Memahami Kearifan Budaya Lokal}

Setiap keperibadian orang dibentuk atas nilai-nilai yang bersumber dari ajaran agama maupun tradisi dan budaya lokal di lingkungan sekitarnya. Setiap tradisi dan budaya tentu memiliki nilai-nilai positif yang mencerminkan kearifan lokal (local wisdom) sendiri yang berbeda antara satu budaya dengan budaya yang lain, termasuk konsep tentang rumah tangga ideal.

Walaupun agama sepatutnya menjadi acuan dan sumber nilai yang utama mengatasi sumber nilai yang lain, seringkali tradisi dan budaya lokal dalam praktik kehidupan seharihari suatu rumah tangga menjadi begitu penting. Karena begitu pentingnya, maka kesalahan dalam memahami dan menempatkan nilai-nilai tradisi dan budaya itu seringkali menjadi penyebab munculnya konflik antarindividu yang berakibat terjadinya tindak KDRT. Oleh karena itu, suami, istri, dan anggota lain dalam rumah tangga dengan latarbelakang tradisi dan budaya yang berbeda perlu memahami dan mengekpresikan nilia-nilai positif budaya masing-masing dalam kesalehan lingual atau kesalehan verbal melalui ucapan dan tuturkata yang santun, sejuk, damai dan menyenangkan. Selain itu, mereka juga dapat menunjukkannya dalam kesalehan sosial melalui perilaku yang sopan, sikap pemaaf, dan sebagainya.

Pemahaman yang memadai tehadap nilai-nilai budaya lokal akan membantu setiap individu tidak sampai terjebak ke dalam pengaruh budaya luar dalam bungkusan globalisasi yang kini gencar melanda seluruh pelosok dunia. Meskipun banyak juga aspek positif yang dapat diserap daripadanya, akan tetapi globalisasi berpotensi kuat menggiring manusia ke arah situasi anomie. Ini cenderung terjadi karena globalisasi antara lain dicirikan oleh derasnya laju transformasi berbagai bentuk budaya, sikap, dan pandangan hidup manusia modern yang tidak semuanya tepat dari sisi pandang budaya lokal (Indonesia) dan agama.

\section{Memperkuat Fondasi dan Bangunan Ekonomi Keluarga}

Menjalani hidup berkeluarga seadanya dalam tingkat kepasarahan yang tinggi tampaknya kini tidak lagi sesuai dalam kehidupan yang semakin kompleks dengan sederatan tuntutan yang mesti dipenuhi. Kompleksitas kehidupan tidak hanya berlaku di perkotaan tetapi juga di pedesaan dengan sejumlah persamaaan dan perbedaannya. Beban hidup yang 
terlalu berat dapat mengakibatkan ketidakseimbangan emosi hingga memicu terjadinya tindakan KDRT. Kerana itu, seluruh anggota dalam suatu rumah tangga sesuai kesanggupan masing-masing harus melakukan usaha-usaha yang dapat memperkuat fondasi dan struktur bangunan ekonomi keluarga mereka.

Tanggungjawab utama memang berada di atas pundak suami. Sebagai kepala keluarga, suami mesti bekerja keras dalam bidang yang ia tekuni dan tidak mudah goyah oleh pengaruh-pengaruh luar yang menyebabkan ia mudah melepaskan pekerjaan utamanya. Selain kukuh dengan pekerjaan utama, suami juga ditunut untuk selalu berusaha mencari peluang untuk dapat melakukan inovasi dan menciptakan kreasi-kreasi baru meskipun tidak sejalan dengan bidang pekerjaannya yang utama.

Selain itu, istri sebagai anggota utama keluarga yang kedua juga dapat melakukan hal yang sama seperti suaminya, lebih-lebih bila dia juga ikut bekerja dalam sektor formal atau informal. Kecuali anak yang sudah bekerja, anak yang sedang menempuh pendidikan tentu tidak dituntut untuk dapat menghasilkan pendapatan tambahan bagi keluarga. Akan tetapi ia tetap dapat melakukan penguatan ekonomi keluarga secara pasif dengan berhemat dan meminta kedua orangtuanya untuk mememenuhi kebutuhannya yang pokok-pokok saja."

\section{Mengamalkan Ajaran Agama}

Agama Islam adalah ajaran yang merupakan sumber dari segala sumber nilai. Sebagai sebuah ajaran, dan bukan sistem nilai, nilai-nilai yang terkandung dalam ajaran Islam akan merasuk dalam hati dan pikiran untuk mendorong pemeluknya membangun sistem nilai sendiri, termasuk dalam kehidupan berkeluarga.

Dalam Surah An-Nisa, ayat 21 dan 154 menegaskan bahwa perkawinan sebagai bentuk kesepakatan yang kokoh (mitsqan ghalizan) yang dibangun di atas landasan prinsip pergaaulan yang antun ('muasyarah bi al-ma'ruf) akan membawa suami, istri, dan seluruh anggota keluarga kepada kehidupan yang damai, tenteram, dan bahagia. Dalam pada itu, sebuah hadits Rasulullah SAW yang diriwayatkan oleh Ahmad ibn Hanbal dari Muawiyah ibn Hidah mengindikasikan pembelaan yang sangat kuat terhadap perempuan dan kecaman terhadap perilaku buruk suami terhadap istri.

\section{KESIMPULAN}

Berdasarkan penelitian di atas dapat disimpulkan :

1. Pada dasarnya keberadaan Kitab Undang-undang Hukum Pidana (KUHP) telah merumuskan pasal-pasal tentang tindak pidana penganiayaan, namun keberadaan pengaturan ini belum dianggap mengakomodir perbuatan pidana yang berkaitan dengan kekerasan dalam rumah tangga. Secara substansi hukum dari pengaturan penganiayaan dalam KUHP pada dasarnya mengandung rumusan hukum yang sama dengan pengaturan UU PKDRT hanya saja UU PKDRT Umum yaitu Undang-Undang Nomor 23 Tahun 2004 tentang Penghapusan Kekerasan Dalam Rumah Tangga

2. Masyarakat pedesaan memandang perlakukan kekerasan Dalam Rumah Tangga sebagian besar dapat menerima begitu saja tampa melakukan perlawanan, hal ini disebabkan karena menganggap perilaku tersebut merupakan suratan hidup, sudah 
Seminar Nasional Penelitian dan Pengabdian kepada Masyarakat Universitas Sang Bumi Ruwa Jurai Tahun 2020

takdir, malu karena menjadi aib keluarga, bahkan ada sebagian petuah orang tua untuk menerima apa saja perlakuan sumai dan selalu harus patuh dengan suami.

\section{DAFTAR PUSTAKA}

Elli N Hasbianto, Kekerasan Dalam Rumah Tangga. Potret Muram Kehidupan Perempuan Dalam Perkawinan. Makalah Disajikan pada Seminar Nasional Perlindungan Perempuan dari pelecehan dan Kekerasan seksual. UGM Yogyakarta, 6 November 1996

Hasbianto, Elli N, Kekerasan Dalam Rumah Tangga. Potret Muram Kehidupan Perempuan Dalam Perkawinan. Makalah Disajikan pada Seminar Nasional Perlindungan Perempuan dari pelecehan dan Kekerasan seksual. UGM Yogyakarta, 6 November 1996.

Harkristuti Harkrisnowo, "Domestic Violence (Kekerasan Dalam Rumah Tangga) Dalam Perspektif Kriminologis Yuridis,” Jurnal Hukum Internasional 1, no. 4 (2004

Johan Galtung, The True World: A Transnational Perspective. New York: The Free Press, 1980, hlm. 67. Lihat juga penjelasannya dalam Mohtar Mas’oed, et.al (eds.),

Komnas Perempuan, Kerentananan Perempuan terhadap Kekerasan Ekonomi dan Kekerasan Seksual: di rumah, institusi pendidikan dan lembaga negara,Catatan KTP tahun 2008, Jakarta: Komnas Perempuan, 2009.

Muhammad, Husein., Kekerasan terhadapPerempuan Perspektif Islam, Makalah disampaikan dalam seminar yang diselenggarakan di PSW STAIN Pekalongan, 28 November 2005

Mohammad Kemal Dermawan, Op. Cit., hlm. 7.32-7.33 (penjelasan lanjut, lihat Hasil Tim Perumus Kelompok Kerja Usulan RUU-KDRT, Rancangan Undang-Undang Kekersan Dalam Rumah Tangga, yang diperbanyak oleh Mitra Perempuan, Juli 1999.

Mohtar Mas'oed, et.al (eds.), Kekerasan Kolektif: Kondisi dan Pemicu. Yogyakarta: P3PK UGM, 2000, hlm. 4

Muhsin, Aminah Wadud, Quran Menurut Perempuan: Membaca Kembali Kitab Suci Dengan Semangat Keadilan, terj. Abdullah Ali, Jakarta: Serambi, 2006.

Mulia, Siti Musdah, Kekerasan dalam rumah tangga; Perpeksif Agama-Agama. Jakarta, 2004.

Munir, Lily Zakiyah, "Domestic Violence in Indonesia," Muslim World Journal of Human Rights: Vol. 2. No. 1, Article 5 (2005).

Nyoman Serikat Putra Jaya, Relevansi Hukum Pidana Adat Dalam Pembaharuan Hukum Pidana Nasional (Bandung: Citra Aditya Bakti, 2005).

Rofiq, Ahmad, Fiqh Kontektual. Dari Normatif ke Pemaknaan Sosial, cet. 1, Yogyakarta: Pustaka Pelajar, 2004. 
Seminar Nasional Penelitian dan Pengabdian kepada Masyarakat Universitas Sang Bumi Ruwa Jurai Tahun 2020

Rober Gurr, Why Men Rebel. Princeton, NJ: Princeton University Press, 1970

Undang-Undang No. 23 Tahun 2004 tentang Penghapusan Kekerasan Dalam Rumah Tangga. 